\title{
Adenocarcinoma of the nasal cavity and sinuses in England and Wales
}

\author{
E. D. ACHESON, R. H. COWDELL, and ELIZABETH RANG \\ Department of Community Medicine, University of Southampton, and Department of \\ Pathology, Radcliffe Infirmary, Oxford
}

\begin{abstract}
Acheson, E. D., Cowdell, R. H., and Rang, Elizabeth (1972). Brit. J. industr. Med., 29, 21-30. Adenocarcinoma of the nasal cavity and sinuses in England and Wales. A survey of nasal adenocarcinoma in England and Wales (excluding the Oxford region) is described. Where possible, occupational details were obtained and the histological material on the basis of which the diagnosis had been made was reassessed. A total of 107 patients with adenocarcinoma (80 men and 27 women) and 110 matched control cases of nasal cancer of other histological types ( 85 men and 25 women) were accepted for analysis. The material was classified according to occupation and the distribution compared with that of the population of England and Wales in 1961. Thirty-four of the adenocarcinoma patients (including one woman) and nine patients in the control group had at some stage of their career worked with wood-the majority in the furniture industry. In addition to providing abundant further evidence of the association between nasal adenocarcinoma and work in the furniture industry the evidence suggests that a smaller but nevertheless material risk of developing other histological types of nasal cancer may exist for workers in the industry. It is probable that certain woodworkers outside the furniture industry are also at risk although the risk is almost certainly very much less than in the furniture industry. An excess of nasal cancer patients who had been leather workers (usually in the boot and shoe making and repairing industries) was also found.
\end{abstract}

Adenocarcinoma of the nasal cavity is a rare tumour. In cancer registers in southern England in which information about the histological classification of tumours is available, adenocarcinomas account for about $8 \%$ of all epithelial malignant tumours of the nasal cavity and accessory sinuses. The average annual incidence in persons over 15 years of age in southern England is 0.8 per million in men and 0.4 in women (Acheson, Cowdell, and Jolles, 1970a).

A national survey of adenocarcinoma of the nasal cavity was prompted by the need to see whether the increased risk of this tumour which had been demonstrated in the Buckinghamshire and Oxfordshire furniture industry extended to furniture workers in other parts of the country. It was hoped that the possibility that other occupational groups might be affected could be examined at the same time.
A letter was written to each of the cancer registries in England, with the exception of the Oxford Regional Register, asking for particulars of all adenocarcinomas of the nasal cavity and sinuses registered in recent years. The Oxford Region was excluded from the study as it had already been the subject of a detailed analysis published elsewhere. In the event, not all registries were able to comply with the request as in some areas no record of the histological type of the tumour is kept. Fortunately these registries were able to respond by supplying data about all registered nasal cancers. Histological material was then sought directly from the hospitals concerned. Most registries provided material covering the years 1961-6, but a few were able to cover a longer span of years.

As a second stage, registries were asked to supply particulars of a control case for each of the adenocarcinomas. The controls were to be patients with nasal cancer 
of a histological type other than adenocarcinoma, of the same sex and within five years of age, registered in the same region and in the same year.

For all cases and controls an attempt was made to obtain a full occupational history. In all but two cases permission to approach the patient or his relatives was obtained, either from the family doctor or from the specialist concerned with the hospital treatment. A letter was then written to the patient or his relatives explaining that an investigation was being made into occupational factors in various diseases of the nose and asking for a simple questionnaire to be completed.

\section{Results}

Table 1 shows the numbers of nasal adenocarcinomas and of control cases ascertained according to the amount of occupational and pathological information available.

A total of 145 nasal adenocarcinomas and 133 controls was ascertained. Slides were obtained and examined by one of us (R.H.C.) in $107(73.8 \%)$ of the adenocarcinomas and in $98(73.7 \%)$ of the controls. The histological classification of adenocarcinoma was not confirmed in $33(22.8 \%)$ of the cases submitted as such, and these have been discarded from the analysis. Among the controls for which slides were available, four cases were reclassified as adenocarcinomas and have been added to the series of adenocarcinomas. Cases ascertained as adenocarcinomas in which it has not been possible to examine sections have been retained.

Table 1 also shows the material classified according to the amount of occupational data received. In $89(61.4 \%)$ of the cases and in $85(63.9 \%)$ of the controls the patient or a relative was contacted and information was received in answer to a questionnaire or by correspondence. In a further $38(26.2 \%)$ of the cases and $29(21.8 \%)$ of the controls, in whom it was not possible to contact the patient or relatives, a small amount of occupational data was obtained either from the hospital records or from the death certificate.
Table 2 shows in summary form the number of cases and controls accepted and rejected for each sex separately. As might be expected, occupational data were lacking in a higher proportion of the women than of the men.

\section{Histological classification}

In Table 3 the 205 cases for which histological material was available for examination are shown according to the original classification and also as reclassified by R.H.C. In considering this Table it is important to remember that it does not represent a rigorous comparison of the interpretation of a series of histological slides by pairs of observers. Many of the differences arise from the fact that the original classification given is often based on the diagnostic grouping used in cancer registries. These frequently do not subdivide tumours of certain sites in the degree of detail used by pathologists so that, for example, adenocarcinomas of minor salivary glands and cylindromas of the nose may be placed in the general category of adenocarcinoma of the nose although they are distinct in both histology and behaviour. Where the pathologist's diagnosis was obtainable, discrepancies were rare and tended to relate to such distinctions as between anaplastic carcinoma and malignant melanoma which do not affect the present argument to any great extent. In our earlier work, the excess of adenocarcinomas in woodworkers stood out unequivocally before statistical study and, to avoid any bias in this direction, we did not include as adenocarcinoma any tumour so necrotic or poorly differentiated as to leave any room for doubt. Most of the adenocarcinomas are remarkably uniform in type, being fairly well differentiated with a papillary columnarcell pattern (Fig. 1), often with plentiful mucus secretion and sometimes with extensive mucoid degeneration (Fig. 2). They invade bone early and several cases have presented initially with meningitis secondary to intracranial spread.

TABLE 1

adenocarcinomas and Controls according to Histological Classification and amount of Occupational Data Received (Percentages in PaRentheses)

\begin{tabular}{|c|c|c|c|c|c|c|c|c|c|}
\hline \multirow{2}{*}{\multicolumn{2}{|c|}{$\begin{array}{l}\text { Histological } \\
\text { classification }\end{array}$}} & \multicolumn{4}{|c|}{$\begin{array}{c}\text { Adenocarcinomas } \\
\text { Occupation }\end{array}$} & \multicolumn{4}{|c|}{$\begin{array}{l}\text { Controls } \\
\text { Occupation }\end{array}$} \\
\hline & & $\begin{array}{c}\text { History } \\
\text { obtained }\end{array}$ & $\begin{array}{c}\text { Incomplete } \\
\text { data }\end{array}$ & $\begin{array}{l}\text { No } \\
\text { data }\end{array}$ & Total & $\begin{array}{c}\text { History } \\
\text { obtained }\end{array}$ & $\begin{array}{c}\text { Incomplete } \\
\text { data }\end{array}$ & $\begin{array}{l}\text { No } \\
\text { data }\end{array}$ & Total \\
\hline $\begin{array}{l}\text { Confirmed } \\
\text { Not confirmed } \\
\text { Slides not obtained }\end{array}$ & $\begin{array}{l}\cdots \\
\cdots \\
\cdots\end{array}$ & $\begin{array}{l}59(40 \cdot 7) \\
14(9 \cdot 7) \\
16(11 \cdot 0)\end{array}$ & $\begin{array}{l}12(8 \cdot 3) \\
10(6 \cdot 9) \\
16(11 \cdot 0)\end{array}$ & $\begin{array}{ll}3 & (2 \cdot 1) \\
9 & (6 \cdot 2) \\
6 & (4 \cdot 1)\end{array}$ & $\begin{array}{ll}74 & (51 \cdot 0) \\
33 & (22 \cdot 8) \\
38 & (26 \cdot 2)\end{array}$ & $\begin{array}{r}66(49 \cdot 6) \\
3(2 \cdot 3) \\
16(12 \cdot 0)\end{array}$ & $\begin{aligned} & 13(9 \cdot 8) \\
& 1(0 \cdot 7) \\
& 15(11 \cdot 3)\end{aligned}$ & $15 \frac{(11 \cdot 3)}{4(3 \cdot 0)}$ & $\begin{array}{rr}94 & (70 \cdot 7) \\
4 & (3 \cdot 0) \\
35 & (26 \cdot 3)\end{array}$ \\
\hline Total & .. & $89(61 \cdot 4)$ & $38(26 \cdot 2)$ & $18(12 \cdot 4)$ & $145(100 \cdot 0)$ & $85(63.9)$ & $29(21 \cdot 8)$ & $19(14 \cdot 3)$ & $133(100 \cdot 0)$ \\
\hline
\end{tabular}


TABLE 2

Numbers (Percentages in Parentheses) of Adenocarcinomas and Controls accepted, and Numbers rejected, giving Reason, for Each Sex Separately

\begin{tabular}{|c|c|c|c|c|c|c|c|c|c|c|}
\hline & & & & & & & \multicolumn{2}{|c|}{ Adenocarcinomas } & \multicolumn{2}{|c|}{ Controls } \\
\hline \multirow{4}{*}{$\begin{array}{l}\text { Accepted } \\
\text { Histology confirmed } \\
\text { Slides not obtained }\end{array}$} & \multirow{4}{*}{$\begin{array}{l}. . \\
.\end{array}$} & \multirow{4}{*}{$\begin{array}{l}. \\
.\end{array}$} & \multirow{4}{*}{$\begin{array}{l}\ldots \\
.\end{array}$} & \multirow{4}{*}{$\begin{array}{l}\ldots \\
.\end{array}$} & \multirow{4}{*}{$\begin{array}{l}. \\
\cdots\end{array}$} & \multirow{4}{*}{$\begin{array}{l}\ldots \\
\ldots\end{array}$} & Males & Females & Males & Females \\
\hline & & & & & & & $59 \quad(57 \cdot 3)$ & $16(34 \cdot 9)$ & $57 \quad(60.6)$ & $22(62.9)$ \\
\hline & & & & & & & $21(20.4)$ & $11(23.9)$ & $28(29 \cdot 8)$ & $3(8.5)$ \\
\hline & & & & & & & $80(77 \cdot 7)$ & $27(58 \cdot 8)$ & $85(90.4)$ & $25(71 \cdot 4)$ \\
\hline \multirow{5}{*}{$\begin{array}{l}\text { Rejected } \\
\text { Histological grounds } \\
\text { No occupational data } \\
\text { On both grounds }\end{array}$} & & & & & & & & & & \\
\hline & .. & .. & .. & .. & .. & .. & $17(16 \cdot 5)$ & $7(15 \cdot 2)$ & - & 一 \\
\hline & .. & $\ldots$ & $\ldots$ & . & . & . & $\begin{array}{ll}3 & (2.9)\end{array}$ & $6(13.0)$ & $\begin{array}{ll}9 & (9 \cdot 6)\end{array}$ & $10(28 \cdot 6)$ \\
\hline & . & . & .. & . & . & . & $3 \quad(2 \cdot 9)$ & $6(13 \cdot 0)$ & - & - \\
\hline & & & & & & & $23(22 \cdot 3)$ & $19(41 \cdot 2)$ & $9 \quad(9 \cdot 6)$ & $10(28.6)$ \\
\hline Total & .. & .. & .. & .. & . & .. & $103(100 \cdot 0)$ & $46(100 \cdot 0)$ & $94(100 \cdot 0)$ & $35(100.0)$ \\
\hline
\end{tabular}

The 4 control cases reclassified as adenocarcinomas have been shown as adenocarcinomas.

TABLE 3

Histological Comparison of THE SLIDES WHich WERE EXAMINED

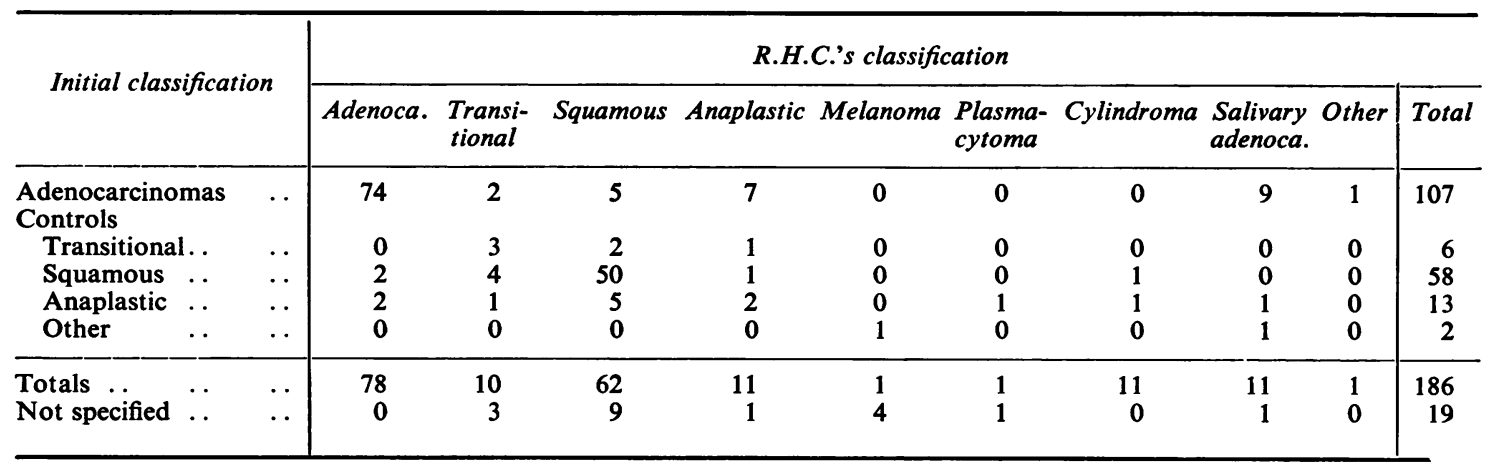

Occupational distribution

Table 4 shows, for men only, the adenocarcinoma cases and the controls classified according to the Registrar General's Classification of Occupations into Orders (1960). Two alternative definitions of occupation are given. The first is based on the occupation of the patient at the time the tumour was diagnosed or, for men who had retired, the last occupation followed. The second is based on the occupation followed for the longest period of time during the man's career. The results of these two classifications are seen to be closely similar. The expected distribution of the cases has been calculated by simple proportion from the distribution of economically active and retired males by occupation at the 1961 census (General Register Office, 1961). Material for the Oxford Region is included in the 1961 census figures from which the expected numbers have been calculated but is excluded from the observed number of cancer cases. The effect of this discrepancy is to increase marginally the expected numbers of woodworkers and leatherworkers and therefore to reduce the contrast between observed and expected.

When the distribution of the adenocarcinoma cases is compared with the expected distribution, the excess of patients with adenocarcinoma who were woodworkers stands out as the most striking feature and, statistically speaking, is highly significant $\left(\chi^{2}=319, \mathrm{n}=1, \mathrm{P}<0.001\right)$. When the woodworkers are divided into those known to have worked mainly in the furniture industry and the 


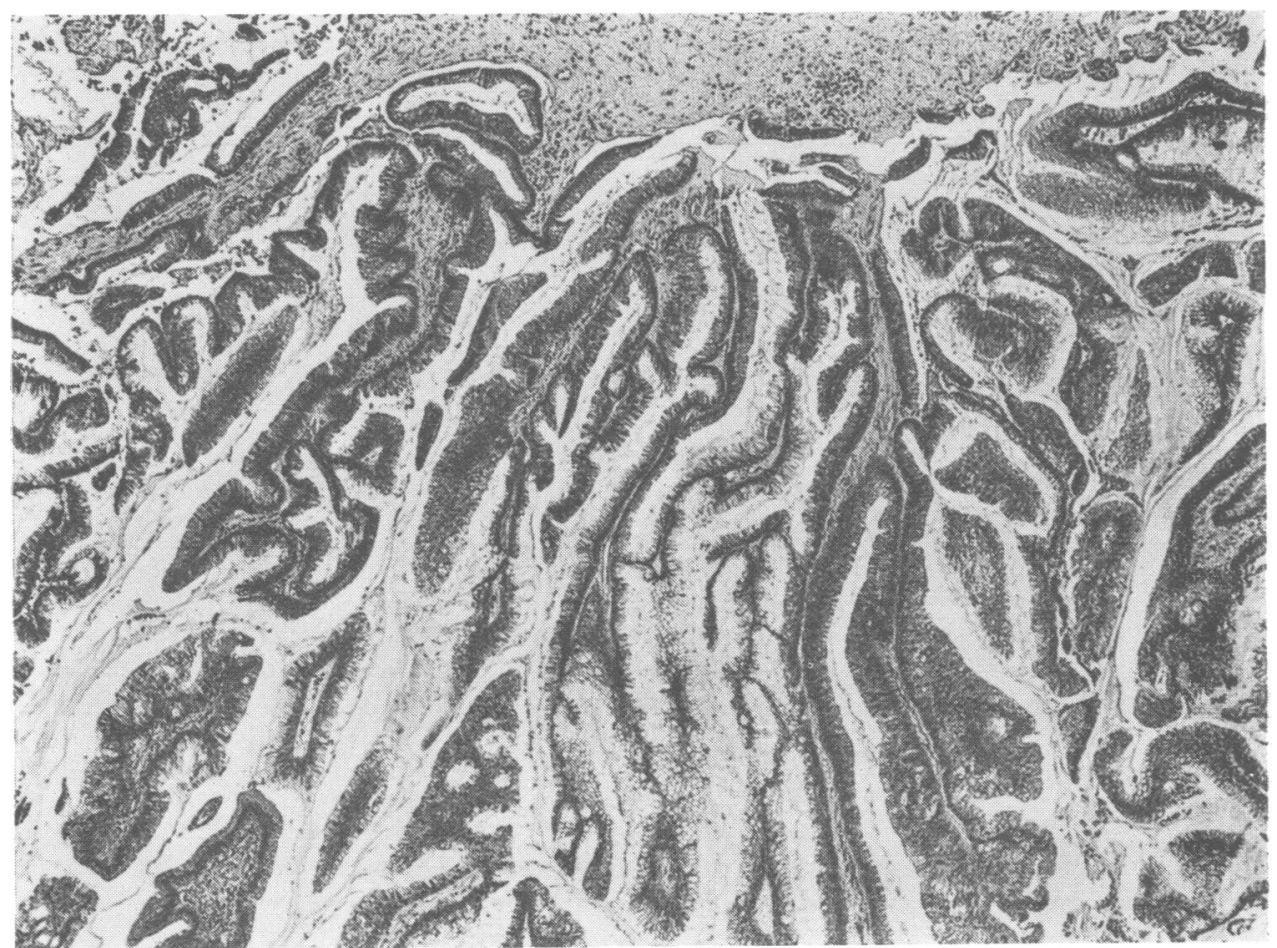

FIG. 1. Papillary mucus-secreting nasal adenocarcinoma. (Haematoxylin and eosin, $\times 90$ )

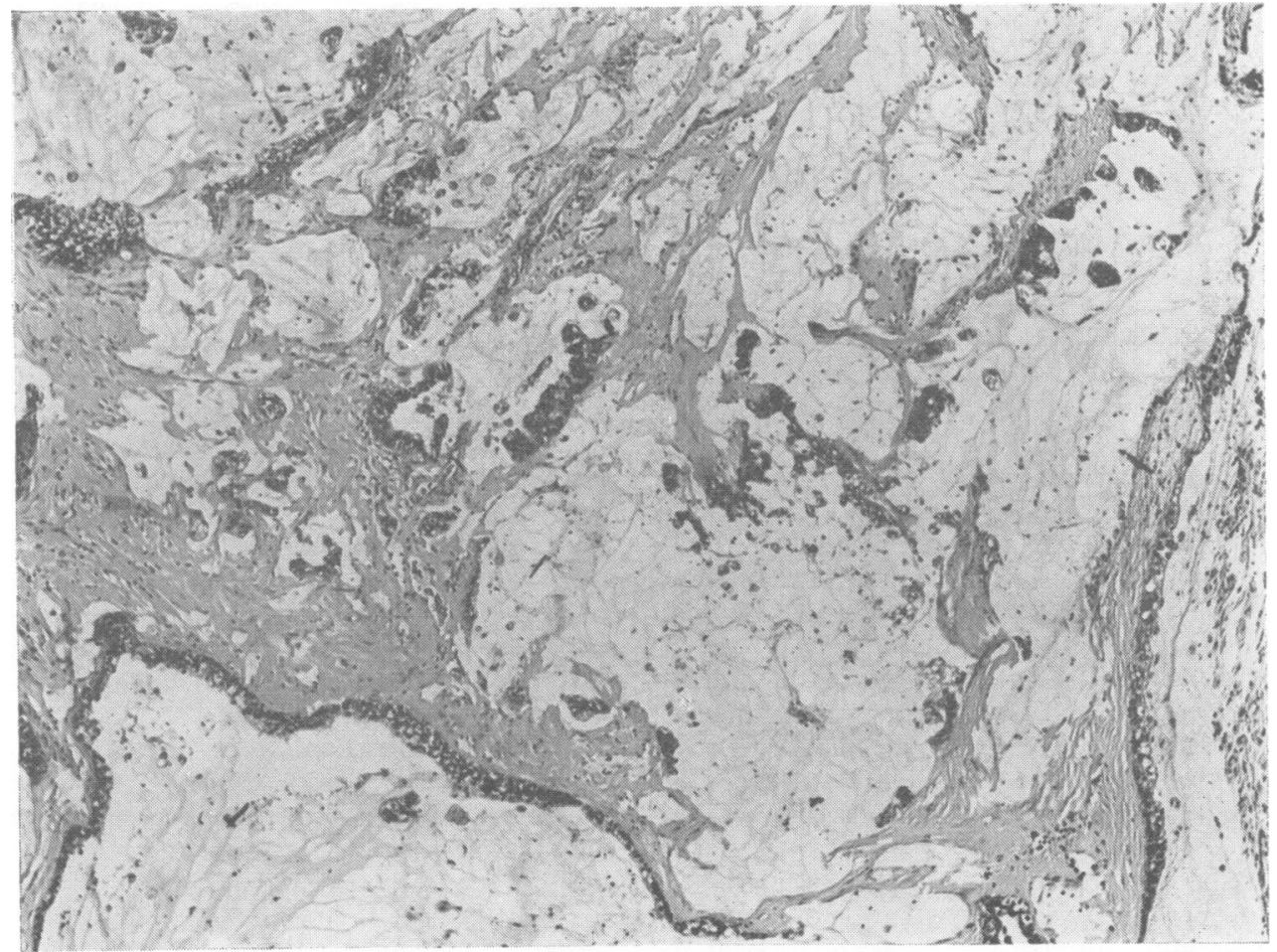

FIG. 2. Mucoid degeneration in same tumour as in Figure 1. (Haematoxylin and eosin, $\times 90$ ) 
TABLE 4

Cases and Controls, including Retired Persons, distributed by Occupational Order (Males only)

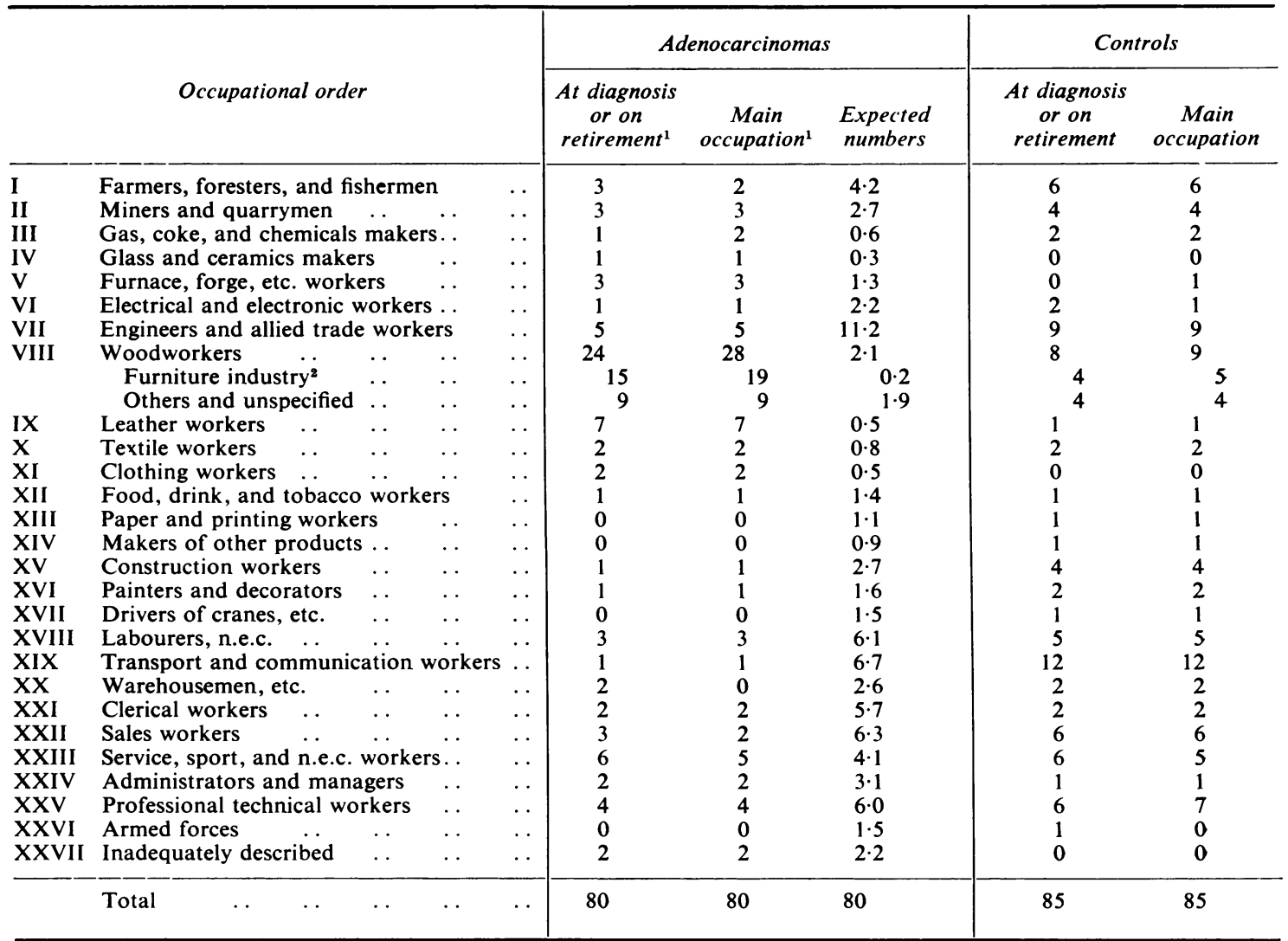

${ }^{1}$ The cases are shown by occupation (a) at diagnosis or on retirement and $(b)$ main occupation.

${ }^{2}$ It has been assumed that all the persons enumerated at the census in occupational category 081 , and about half those in category 082 , were working in the furniture industry.

remainder (principally carpenters and joiners), we find that the ratio of observed to expected cases is much higher among the furniture workers (95 to 1) than among the others (5 to 1). The excess risk in furniture workers would appear even greater if two cases in carpenters who worked for a short time in the industry, and one case in a wood machinist and one in a woodworker, the nature of whose work is uncertain, were classified with them. Of the other occupational orders, only the leather workers (order IX) have an unequivocal excess of adenocarcinoma cases $\left(\chi^{2}=84, \mathrm{n}=1, \mathrm{P}<0.001\right)$.

The distribution of the control nasal cancer cases is much closer to the expected distribution. It is worth noting, however, that there is also a significant excess of nasal cancers other than adenocarcinomas among woodworkers $\left(\chi^{2}=23, \mathrm{n}=1\right.$, $P<0.001)$. In this group the greater relative risk once again appears to be among the furniture workers. Such an excess is not surprising since a proportion of the anaplastic carcinomas may be presumed to be of glandular origin, and squamous metaplasia in the nose is a common phenomenon. The significance of the twofold excess of transport and communication workers (order XIX) is doubtful. The majority of these cases occurred among road vehicle drivers (occupations 195, 196, and 197) but these occupations constitute together more than half the population of this order.

Occupational data for the female adenocarcinoma cases and for their controls is less adequate than for the men. This stems from the unfortunate tendency on hospital records and on death certificates to classify women in terms of their husband's occupation. Another contributing factor may be that elderly deceased female patients less frequently have living relatives who can give an occupational history than have the deceased males. For these 
reasons, 12 of the $46(26.1 \%)$ female adenocarcinoma cases and 10 of $35(28.6 \%)$ controls had no occupational data available. Of those for whom there were occupational data a greater proportion of the adenocarcinomas (24 out of $34-70.6 \%$ ) than of the controls (12 out of $25-48.0 \%$ ) had spent much or most of their lives employed outside the home. However, the difference between these two proportions is not significant $\left(\chi^{2}=2 \cdot 2, \mathrm{P}<0.10\right.$ where $\mathbf{n}=1$ ).

Due to the small numbers involved and the problems of classification, not much can be deduced from the distribution by occupation of the female adenocarcinoma cases and controls. Of the 24 women with adenocarcinoma who were classified as having been 'economically active' for much of their lives, one was a wood stainer and one an upholsterer who had also worked in the glove trade (cases 427 and 531). Five of the adenocarcinoma cases (one expected) and two of the controls $(0.5$ expected) had worked for long periods in the textile industry. With these exceptions the distributions were roughly as expected.

In Table 5 historical details are listed for all patients for whom we have information that they engaged at any time in woodwork or in one of the leather trades. Historical details of persons who worked in the textile and clothing industry are shown in Table 6.

Table 5a consists of 29 workers (of whom 28 are male and one female) who at some time are known to have worked in the furniture industry. Twentyfive of these workers suffered from adenocarcinoma, three from squamous tumours, and one from a transitional-cell tumour. Nine of them did not appear in Table 4 as woodworkers because their main occupation or their occupation at diagnosis or on retirement was classified in one of the other orders. Two others (cases 416 and 417) were classified as carpenters and joiners. Of the 29 subjects, 13 had been cabinet or chairmakers, nine were wood machinists, turners or sawyers, three were woodworkers of unspecified craft, two were upholsterers, one was a wood stainer, and one was a French polisher.

Table $5 \mathrm{~b}$ consists of eight male woodworkers for whom we have detailed occupational information, and for whom there is no evidence that they ever worked in the furniture industry; six had adenocarcinomas and two had squamous tumours. Six additional cases (Table 5c) are shown in whom it is uncertain whether or not they worked in the furniture industry.

Table 5d shows particulars of 12 persons, of whom 10 are men and two women, who at some time worked in one of the leather trades, eight with adenocarcinoma and four with squamous tumours. Once again, those who do not appear as leather workers in Table 4, because their principal occupation and their occupation at the time the tumour was diagnosed or on retirement was in a different field, or because they are female, are indicated by asterisks.

Workers in the textile industry The analysis of the tumours in female subjects of the survey according to main occupation suggested that there might be an excess of textile workers with adenocarcinoma and possibly other types of tumour. Although the numbers are very small. the distribution of cases and controls in males by occupation (Table 4) supports this suggestion. A search was therefore made within the survey for persons who had spent short periods in the textile industry in addition to the seven women already referred to and the four men in Table 4 whose principal occupation, or occupation at diagnosis or on retirement, had been in the textile industry. Six additional cases were found, three with adenocarcinomas and three with other tumours (excluding the two upholsterers who also had had contact with wood dust and the upholsterer(case 531) who had worked in the Yeovil glove trade) to add to the 11 textile workers already known. In addition, three adenocarcinoma cases were found in patients who had been exposed to the dust of textiles in the clothing industry (cases 445,476 , and 518). The occupational details of all 20 cases are shown in Table 6. Nine of the adenocarcinoma cases and five of the controls had been exposed to cotton dust either in the spinning or weaving processes or in the clothing trade. Four adenocarcinoma cases and two controls had been exposed to the dusts of other textiles including wool (4), fur and felt (1), and linen (1). The dressmaker (case 476) was exposed to the dust of various types of material including cotton but the actual amount of dust was small.

\section{Discussion}

This study provides additional evidence of the relationship between work in the furniture industry and the development of nasal adenocarcinoma. This relationship was first demonstrated in a detailed survey of nasal cancer in Oxfordshire, Buckinghamshire, and Berkshire (Acheson, Cowdell, Hadfield, and Macbeth, 1968). Subsequently case reports have been published from Belgium (Debois, 1969), France (Gignoux and Bernard, 1969), and Denmark (Mosbech and Acheson, 1971). In Britain, nasal adenocarcinoma in the furniture-making industry is now a prescribed industrial disease, and the study reported here confirms that a risk of nasal adenocarcinoma exists throughout the British furniture industry and is not limited to the Oxford Region.

The strong suggestion from Table 4 that there is also an increased risk of histological types of tumour 
TABLE 5

(b) WOODWORKERS NOT IN THE FURNITURE INDUSTRY

\begin{tabular}{|c|c|c|c|c|c|c|c|c|c|c|c|c|}
\hline Case & Sex & $\begin{array}{r}Y e \\
B i r t h\end{array}$ & $\begin{array}{l}\text { ar of } \\
\text { Entry to } \\
\text { industry }\end{array}$ & $\begin{array}{l}\text { Nature of } \\
\text { industry }\end{array}$ & $\begin{array}{l}\text { Occupation } \\
\text { in industry }\end{array}$ & $\begin{array}{c}\text { Year } \\
\text { left } \\
\text { industry }\end{array}$ & $\begin{array}{c}\text { District where } \\
\text { employed }\end{array}$ & $\begin{array}{c}\text { Year of } \\
\text { diagnosis }\end{array}$ & Histology & $\begin{array}{l}\text { Principal types } \\
\text { of dust to } \\
\text { which exposed }\end{array}$ & $\begin{array}{l}\text { Site of } \\
\text { tumour }\end{array}$ & Other work \\
\hline 403 & $\mathbf{M}$ & 1909 & 1922 & $\begin{array}{l}\text { Building } \\
\text { contractor }\end{array}$ & Joiner & $\underset{\text { known }}{\text { Un- }}$ & Blackburn & 1966 & Adeno & Soft woods & $\begin{array}{l}\text { L. nasal } \\
\text { cavity }\end{array}$ & \\
\hline 404 & $\mathbf{M}$ & 1890 & 1904 & Builder & $\begin{array}{l}\text { Joiner and } \\
\text { carpenter }\end{array}$ & 1965 & Macclesfield & 1965 & Adeno & Soft woods & $\begin{array}{l}\text { L. } \max \text {. } \\
\text { antrum }\end{array}$ & \\
\hline 411 & $\mathbf{M}$ & 1904 & 1919 & Builder & Joiner & 1962 & London & 1962 & Adeno & Unknown & $\begin{array}{l}\text { L. } \\
\text { ethmoids }\end{array}$ & \\
\hline 412 & $\mathbf{M}$ & 1910 & 1925 & Builder & Joiner & $\begin{array}{c}\text { Un- } \\
\text { known }\end{array}$ & Stockport & 1964 & Adeno & Soft woods & Ethmoids & \\
\hline 424 & $\mathbf{M}$ & 1901 & 1917 & $\begin{array}{l}\text { Own } \\
\text { business }\end{array}$ & $\begin{array}{l}\text { Wheelwright, } \\
\text { carpenter, } \\
\text { undertaker }\end{array}$ & 1960 & Norfolk & 1964 & Adeno & Unknown & $\begin{array}{l}\text { Max. } \\
\text { antrum }\end{array}$ & Smallholder \\
\hline 425 & $\mathbf{M}$ & 1901 & 1919 & $\begin{array}{l}\text { Timber } \\
\text { yard }\end{array}$ & Sawyer & 1964 & Norfolk & 1965 & & & Ethmoids & $\begin{array}{l}\text { Timber } \\
\text { merchant }\end{array}$ \\
\hline 511 & $\mathbf{M}$ & 1879 & 1901 & $\begin{array}{l}\text { Packing } \\
\text { firm }\end{array}$ & $\begin{array}{l}\text { Packing case } \\
\text { maker }\end{array}$ & 1955 & London & 1964 & Squamous & Soft woods & $\begin{array}{l}\text { Nasal } \\
\text { cavity }\end{array}$ & \\
\hline 514 & $\mathbf{M}$ & 1919 & (1923) & Builder & Carpenter & $\begin{array}{c}\text { Un- } \\
\text { known }\end{array}$ & London & 1967 & Squamous & Unknown & $\begin{array}{l}\text { Max. } \\
\text { antrum }\end{array}$ & \\
\hline
\end{tabular}

(c) WoOdWorkers Where LitTle Occupational Detail is KNOWN

\begin{tabular}{|c|c|c|c|c|c|c|c|c|c|c|c|c|}
\hline Case & Sex & Birth & $\begin{array}{l}\text { En of } \\
\text { Entry to } \\
\text { industry }\end{array}$ & $\begin{array}{l}\text { Nature of } \\
\text { industry }\end{array}$ & $\begin{array}{l}\text { Occupation } \\
\text { in industry }\end{array}$ & $\begin{array}{c}\text { Year } \\
\text { left } \\
\text { industry }\end{array}$ & $\begin{array}{l}\text { District where } \\
\text { employed }\end{array}$ & $\begin{array}{c}\text { Year of } \\
\text { diagnosis }\end{array}$ & Histology & $\begin{array}{l}\text { Principal types } \\
\text { of dust to } \\
\text { which exposed }\end{array}$ & $\begin{array}{l}\text { Site of } \\
\text { tumour }\end{array}$ & Other work \\
\hline 413 & $\mathbf{M}$ & $\underset{\text { known }}{\text { Un- }}$ & $\underset{\text { known }}{\text { Un- }}$ & Unknown & $\begin{array}{l}\text { Carpenter and } \\
\text { joiner }\end{array}$ & $\begin{array}{c}\text { Un- } \\
\text { known }\end{array}$ & Birmingham & 1964 & Adeno & Unknown & L. nose & \\
\hline 415 & $\mathbf{M}$ & 1892 & , , & ,, & $\begin{array}{l}\text { Wood } \\
\text { machinist }\end{array}$ & ,, & Birmingham & 1963 & Adeno & , , & Ethmoids & \\
\hline 417 & $\mathbf{M}$ & 1914 & ," & " & Wood worker & , , & Newcastle & 1969 & Adeno & , & Ethmoids & \\
\hline 533 & $\mathbf{M}$ & 1902 & , , & , , & $\begin{array}{l}\text { Labourer in } \\
\text { carpenter's shop }\end{array}$ & , , & Birmingham & 1963 & Squamous & , , & Nostril & \\
\hline 534 & $\mathbf{M}$ & 1884 & , & , & Carpenter & ,, & Sheffield & 1961 & $\begin{array}{l}\text { Malignant } \\
\text { polyp }\end{array}$ & ,, & Nasal & \\
\hline 535 & $\mathbf{M}$ & 1899 & , , & , & Carpenter & , & Leeds & $\begin{array}{c}\text { Un- } \\
\text { known }\end{array}$ & $\begin{array}{l}\text { Transi- } \\
\text { tional } \\
\text { papillo- } \\
\text { matosis }\end{array}$ & ,', & Unknown & \\
\hline
\end{tabular}

(d) LEATHERWORKERS ${ }^{1}$

\begin{tabular}{|c|c|c|c|c|c|c|c|c|c|c|c|c|}
\hline Case & Sex & $\begin{array}{r}\text { Ye } \\
\text { Birth }\end{array}$ & $\begin{array}{l}\text { ar of } \\
\text { Entry to } \\
\text { industry }\end{array}$ & $\begin{array}{l}\text { Nature of } \\
\text { industry }\end{array}$ & $\begin{array}{l}\text { Occupation } \\
\text { in industry }\end{array}$ & $\begin{array}{c}\text { Year } \\
\text { left } \\
\text { industry }\end{array}$ & $\begin{array}{l}\text { District where } \\
\text { employed }\end{array}$ & $\begin{array}{c}\text { Year of } \\
\text { diagnosis }\end{array}$ & Histology & $\begin{array}{l}\text { Principal types } \\
\text { of dust to } \\
\text { which exposed }\end{array}$ & $\begin{array}{l}\text { Site of } \\
\text { tumour }\end{array}$ & Other work \\
\hline 441 & $\mathbf{M}$ & 1873 & 1887 & $\begin{array}{l}\text { Boot repair } \\
\text { shop }\end{array}$ & Leather cutter & 1945 & Newcastle & 1961 & Adeno & Leather & Unknown & $\begin{array}{l}\text { Manager of } \\
\text { public house }\end{array}$ \\
\hline 442 & $\mathbf{M}$ & 1907 & 1921 & $\begin{array}{l}\text { Shoe repair } \\
\text { shop }\end{array}$ & Shoe repairer & 1934 & Birmingham & 1962 & Adeno & Leather & Unknown & Miner ${ }^{\prime}$ \\
\hline 494 & $\mathbf{M}$ & 1902 & 1919 & $\begin{array}{l}\text { Footwear, } \\
\text { retailer, and } \\
\text { repairer }\end{array}$ & $\begin{array}{l}\text { Supervision } \\
\text { of workshop } \\
\text { for repair }\end{array}$ & & London & 1964 & Adeno & $\begin{array}{l}\text { Leather and } \\
\text { rubber }\end{array}$ & Antrum & \\
\hline 502 & $\mathbf{M}$ & 1907 & (1922) & $\begin{array}{l}\text { Leather } \\
\text { goods } \\
\text { retailer and } \\
\text { repairer }\end{array}$ & Shoe repairer & & Gloucester & 1964 & Adeno & $\begin{array}{l}\text { Leather and } \\
\text { rubber }\end{array}$ & $\begin{array}{l}\text { Antro- } \\
\text { ethmoid }\end{array}$ & \\
\hline 505 & $\mathbf{M}$ & 1879 & 1895 & $\begin{array}{l}\text { Shoe } \\
\text { factory }\end{array}$ & $\begin{array}{l}\text { Shoe factory } \\
\text { worker }\end{array}$ & & Bristol & 1962 & Adeno & Leather & Ethmoids & \\
\hline 450 & $\mathbf{M}$ & 1914 & 1928 & $\begin{array}{l}\text { Shoe } \\
\text { factory }\end{array}$ & Shoemaker & 1968 & Newcastle & 1965 & Adeno & Leather & Ethmoids & \\
\hline 506 & $\mathbf{M}$ & 1908 & 1922 & $\begin{array}{l}\text { Shoe } \\
\text { repair shop }\end{array}$ & Shoe repairer & 1967 & $\begin{array}{l}\text { Weston- } \\
\text { super-Mare }\end{array}$ & 1965 & & $\begin{array}{l}\text { Leather and } \\
\text { rubber }\end{array}$ & $\begin{array}{l}\text { Nasal } \\
\text { cavity }\end{array}$ & \\
\hline 516 & $\mathbf{M}$ & 1907 & 1922 & $\begin{array}{l}\text { Shoe } \\
\text { factory }\end{array}$ & $\begin{array}{l}\text { Finisher until } \\
1927 \text {; later } \\
\text { cleaned floors } \\
\text { and dust } \\
\text { extractor plant }\end{array}$ & & Norwich & 1967 & Squamous & $\begin{array}{l}\text { Leather and } \\
\text { rubber }\end{array}$ & $\begin{array}{l}\text { Max. } \\
\text { antrum }\end{array}$ & \\
\hline 517 & $\mathbf{M}$ & 1896 & 1910 & $\begin{array}{l}\text { Boot and } \\
\text { shoe factory }\end{array}$ & $\begin{array}{l}\text { Boot and shoe } \\
\text { operative }\end{array}$ & 1914 & & 1964 & & $\begin{array}{l}\text { Leather and } \\
\text { rubber }\end{array}$ & $\begin{array}{l}\text { Max. } \\
\text { antrum }\end{array}$ & 'Bus driver' \\
\hline 515 & $\mathbf{M}$ & 1910 & 1924 & $\begin{array}{l}\text { Boot and } \\
\text { shoe factory }\end{array}$ & Shoe maker & & Somerset & 1964 & Squamous & Leather & $\begin{array}{l}\text { Max. } \\
\text { antrum }\end{array}$ & $\begin{array}{l}\text { Hospital } \\
\text { orderly }\end{array}$ \\
\hline 530 & $\mathbf{F}$ & 1891 & 1914 & Home & & 1918 & & 1961 & Squamous & & & $\begin{array}{l}\text { Cleaner of } \\
\text { offices }^{1}\end{array}$ \\
\hline 531 & $\mathbf{F}$ & 1908 & 1923 & & $\begin{array}{l}\text { 1923-4 Yeovil } \\
\text { glove trade; } \\
1929-45 \\
\text { Upholstery }\end{array}$ & & Somerset & 1964 & Adeno & & Unknown & \\
\hline
\end{tabular}

${ }^{1}$ Details of all these cases except 502 (1091) have been published in a previous paper (Acheson, Cowdell, and Jolles, 1970a). 
TABLE 5

(a) WORKERS IN THE FURNITURE INDUSTRY

\begin{tabular}{|c|c|c|c|c|c|c|c|c|c|c|c|c|}
\hline Case & Sex & Bec & $\begin{array}{l}\text { ar of } \\
\text { Entry to } \\
\text { industry }\end{array}$ & $\begin{array}{l}\text { Nature of } \\
\text { industry }\end{array}$ & $\begin{array}{l}\text { Occupation } \\
\text { in industry }\end{array}$ & $\begin{array}{c}\text { Year } \\
\text { left } \\
\text { industry }\end{array}$ & $\begin{array}{c}\text { District where } \\
\text { employed }\end{array}$ & $\begin{array}{c}\text { Year of } \\
\text { diagnosis }\end{array}$ & Histology & $\begin{array}{l}\text { Principal types } \\
\text { of dust to } \\
\text { which exposed }\end{array}$ & $\begin{array}{l}\text { Site of } \\
\text { tumour }\end{array}$ & Other work \\
\hline 401 & $\mathbf{M}$ & 1905 & (1919) & $\begin{array}{l}\text { Furniture } \\
\text { maker }\end{array}$ & Cabinet maker & 1951 & London & 1964 & Adeno & Unknown & Ethmoids & $\begin{array}{l}\text { GPO as } \\
\text { telephonist }\end{array}$ \\
\hline 402 & $\mathbf{M}$ & 1908 & 1915 & $\begin{array}{l}\text { Own } \\
\text { business }\end{array}$ & Wood turner & 1955 & London & 1964 & Adeno & Unknown & Ethmoids & $\begin{array}{l}\text { Storeman in } \\
\text { TV factory }\end{array}$ \\
\hline 405 & $\mathbf{M}$ & 1900 & 1919 & $\begin{array}{l}\text { Radio } \\
\text { cabinets }\end{array}$ & Cabinet maker & 1940 & Essex & 1961 & Adeno & $\begin{array}{l}\text { Mahogany, } \\
\text { oak, beech }\end{array}$ & $\begin{array}{l}\text { Nasal } \\
\text { cavity }\end{array}$ & $\begin{array}{l}\text { Making } \\
\text { scientific } \\
\text { instruments }{ }^{1}\end{array}$ \\
\hline 406 & $\mathbf{M}$ & 1888 & 1903 & Not known & $\begin{array}{l}\text { Wood worker } \\
\text { and machinist }\end{array}$ & 1952 & Birmingham & 1959 & Adeno & Unknown & Ethmoids & \\
\hline 407 & $\mathbf{M}$ & 1895 & 1906 & $\begin{array}{l}\text { Furniture } \\
\text { manufact.; } \\
\text { undertakers }\end{array}$ & Spindle moulder & 1959 & Essex & 1959 & Adeno & $\begin{array}{l}\text { Oak, } \\
\text { mahogany, } \\
\text { walnut, birch, } \\
\text { elm }\end{array}$ & Unknown & \\
\hline 408 & $\mathbf{M}$ & 1917 & 1933 & $\begin{array}{l}\text { Church } \\
\text { furniture; } \\
\text { aircraft } \\
\text { parts }\end{array}$ & Wood worker & 1948 & Leeds & 1965 & Adeno & $\begin{array}{l}\text { Oak, spruce, } \\
\text { birch }\end{array}$ & $\begin{array}{l}\text { Nasal } \\
\text { cavity }\end{array}$ & Farmer $^{1}$ \\
\hline 409 & $\mathbf{M}$ & 1895 & 1909 & $\begin{array}{l}\text { Furniture } \\
\text { manufact. }\end{array}$ & $\begin{array}{l}\text { Wood } \\
\text { machinist }\end{array}$ & 1940 & $\begin{array}{l}\text { Preston, } \\
\text { Lancs }\end{array}$ & 1961 & Adeno & $\begin{array}{l}\text { Oak, } \\
\text { mahogany, } \\
\text { beech }\end{array}$ & Ethmoids & $\begin{array}{l}\text { Commercial } \\
\text { traveller }\end{array}$ \\
\hline 410 & $\mathbf{M}$ & 1906 & 1920 & $\begin{array}{l}\text { Furniture } \\
\text { manufact. }\end{array}$ & Wood turner & 1964 & Ipswich & 1964 & Adeno & $\begin{array}{l}\text { Oak, walnut, } \\
\text { beech, ash, } \\
\text { elm, birch }\end{array}$ & Ethmoids & \\
\hline 416 & $\mathbf{M}$ & 1903 & 1917 & $\begin{array}{l}\text { Furniture } \\
\text { trade; } \\
\text { shop- } \\
\text { fitting }\end{array}$ & $\begin{array}{l}\text { Cabinet maker } \\
\text { Carpenter }^{2}\end{array}$ & $\begin{array}{l}1926 \\
1968\end{array}$ & Norwich & 1967 & Adeno & $\begin{array}{l}\text { Oak, teak, } \\
\text { deal, } \\
\text { mahogany, } \\
\text { walnut, } \\
\text { alder, birch }\end{array}$ & $\begin{array}{l}\text { Nasal } \\
\text { cavity }\end{array}$ & \\
\hline 417 & $\mathbf{M}$ & 1916 & 1931 & $\begin{array}{l}\text { Furniture } \\
\text { trade; } \\
\text { building } \\
\text { firms }\end{array}$ & $\begin{array}{l}\text { Circular saw } \\
\text { operator } \\
\text { Joiner }{ }^{2}\end{array}$ & $\begin{array}{c}1937 \\
1945-67\end{array}$ & Leeds & 1964 & Adeno & Unknown & $\begin{array}{l}\text { Nasal } \\
\text { cavity }\end{array}$ & \\
\hline 419 & $\mathbf{M}$ & (1904) & 1919 & $\begin{array}{l}\text { Furniture } \\
\text { factory }\end{array}$ & $\begin{array}{l}\text { Wood } \\
\text { machinist }\end{array}$ & 1966 & Barnstaple & 1964 & Adeno & $\begin{array}{l}\text { Oak, } \\
\text { mahogany, } \\
\text { walnut, beech }\end{array}$ & Unknown & \\
\hline 420 & $\mathbf{M}$ & 1905 & (1919) & $\begin{array}{l}\text { Furniture } \\
\text { manufact. }\end{array}$ & Cabinet maker & 1964 & London & 1964 & Adeno & Unknown & $\begin{array}{l}\text { Nasal } \\
\text { cavity }\end{array}$ & \\
\hline 421 & $\mathbf{M}$ & 1903 & (1917) & Not known & Cabinet maker & 1961 & Norwich & 1961 & Adeno & Unknown & Ethmoids & \\
\hline 422 & $\mathbf{M}$ & 1904 & 1919 & $\begin{array}{l}\text { Furniture } \\
\text { manufact. }\end{array}$ & Wood worker & 1930 & Norwich & 1968 & Adeno & Unknown & Ethmoids & $\begin{array}{l}\text { Demolition } \\
\text { worker }^{1}\end{array}$ \\
\hline 423 & $\mathbf{M}$ & 1907 & 1921 & $\begin{array}{l}\text { Furniture } \\
\text { factory }\end{array}$ & $\begin{array}{l}\text { Wood } \\
\text { machinist }\end{array}$ & 1942 & $\begin{array}{l}\text { Wellington, } \\
\text { Salop }\end{array}$ & 1959 & Adeno & Unknown & Antrum & $\begin{array}{l}\text { Instrument } \\
\text { fitter }\end{array}$ \\
\hline 426 & $\mathbf{M}$ & 1886 & 1900 & $\begin{array}{l}\text { Furniture } \\
\text { manufact. }\end{array}$ & $\begin{array}{l}\text { Wood } \\
\text { machinist }\end{array}$ & 1958 & $\begin{array}{l}\text { Solihull, } \\
\text { Warw. }\end{array}$ & 1969 & Adeno & Unknown & Unknown & \\
\hline 428 & $\mathbf{M}$ & 1904 & (1918) & $\begin{array}{l}\text { Furniture } \\
\text { maker }\end{array}$ & Cabinet maker & $\begin{array}{c}1968 \\
\text { (Died) }\end{array}$ & Bromley & 1968 & Adeno & $\begin{array}{l}\text { Mahogany, } \\
\text { teak, iroka, } \\
\text { oak }\end{array}$ & $\begin{array}{l}\text { Maxillary } \\
\text { antrum }\end{array}$ & \\
\hline 429 & $\mathbf{M}$ & 1911 & 1922 & $\begin{array}{l}\text { Furniture } \\
\text { maker }\end{array}$ & Wood worker & & Pontefract & 1965 & Adeno & Unknown & $\begin{array}{l}\text { Nasal } \\
\text { cavity }\end{array}$ & \\
\hline 430 & $\mathbf{M}$ & 1909 & 1923 & $\begin{array}{l}\text { Chair } \\
\text { maker }\end{array}$ & Chair maker & $\begin{array}{l}1965 \\
\text { (Died) }\end{array}$ & London & 1965 & Adeno & Unknown & Unknown & \\
\hline 431 & $\mathbf{M}$ & 1918 & 1932 & $\begin{array}{l}\text { Furniture } \\
\text { maker }\end{array}$ & Cabinet maker & $\begin{array}{c}1965 \\
\text { (Died) }\end{array}$ & London & 1965 & Adeno & Unknown & Antrum & \\
\hline 448 & $\mathbf{M}$ & 1890 & 1904 & $\begin{array}{l}\text { Furniture } \\
\text { factory }\end{array}$ & Cabinet maker & 1926 & Worcester & 1959 & Adeno & Unknown & $\begin{array}{l}\text { Nasal } \\
\text { cavity }\end{array}$ & $\begin{array}{l}\text { Licensee to } \\
\text { death }\end{array}$ \\
\hline 470 & $\mathbf{M}$ & 1909 & 1923 & $\begin{array}{l}\text { Furniture } \\
\text { maker }\end{array}$ & Cabinet maker & 1927 & Plymouth & 1964 & Adeno & Unknown & Unknown & $\begin{array}{l}\text { Building trade } \\
\text { as labourer }\end{array}$ \\
\hline 427 & $\mathbf{F}$ & $\begin{aligned} 1903 \mathrm{~L} \\
\mathrm{k}\end{aligned}$ & $\begin{array}{l}\text { Un- } \\
\text { known }\end{array}$ & $\begin{array}{l}\text { Furniture } \\
\text { maker }\end{array}$ & Wood stainer & $\underset{\text { known }}{\text { Un- }}$ & Norwich & 1965 & Adeno & Unknown & $\begin{array}{l}\text { Maxillary } \\
\text { antrum }\end{array}$ & 1 \\
\hline 473 & $\mathbf{M}$ & 1916 & 1930 & $\begin{array}{l}\text { Furniture } \\
\text { maker }\end{array}$ & Upholsterer & 1939 & Bristol & 1964 & Adeno & $\begin{array}{l}\text { Flock, fibre, } \\
\text { horsehair, and } \\
\text { wood dust }\end{array}$ & Unknown & $\begin{array}{l}\text { Coach } \\
\text { trimmer }\end{array}$ \\
\hline 414 & $\mathbf{M}$ & 1912 & 1926 & $\begin{array}{l}\text { Furniture } \\
\text { maker }\end{array}$ & Upholsterer & & Liverpool & 1967 & Adeno & $\begin{array}{l}\text { Fibre, coir } \\
\text { flock, and } \\
\text { wood dust }\end{array}$ & Unknown & 1 \\
\hline 510 & $\mathbf{M}$ & 1909 & 1925 & Shipyards & French polisher & 1959 & Newcastle & 1959 & Squamous & Unknown & $\begin{array}{l}\text { Nasal } \\
\text { cavity }\end{array}$ & 1 \\
\hline 512 & $\mathbf{M}$ & $1907 \mathrm{~L}$ & $\begin{array}{l}\text { Un- } \\
\text { known }\end{array}$ & $\begin{array}{l}\text { Furniture } \\
\text { factory }\end{array}$ & Cabinet maker & $\begin{array}{c}\text { Un- } \\
\text { known }\end{array}$ & London & 1959 & $\begin{array}{c}\text { Transi- } \\
\text { tional }\end{array}$ & Unknown & Ethmoids & \\
\hline 513 & $\mathbf{M}$ & 1886 & 1899 & $\begin{array}{l}\text { Furniture } \\
\text { factory } \\
\text { (office) }\end{array}$ & Cabinet maker & 1961 & London & 1964 & Squamous & Unknown & Antrum & \\
\hline 532 & $\mathbf{M}$ & 1899 & 1915 & $\begin{array}{l}\text { Furniture } \\
\text { factory }\end{array}$ & Cabinet maker & 1956 & Norwich & 1961 & Squamous & Unknown & Ethmoids & \\
\hline
\end{tabular}

${ }^{1}$ On main occupational table not listed as woodworker.

${ }^{2}$ Noted as carpenter on main table. 
TABLE 6

Workers in TeXtile and Clothing Industry

\begin{tabular}{|c|c|c|c|c|c|c|c|c|c|c|c|c|}
\hline Case & Sex & $\begin{array}{r}Y e \\
\text { Birth }\end{array}$ & $\begin{array}{l}\text { ar of } \\
\text { Entry to } \\
\text { industry }\end{array}$ & $\begin{array}{l}\text { Nature of } \\
\text { industry }\end{array}$ & $\begin{array}{l}\text { Occupation in } \\
\text { industry }\end{array}$ & $\begin{array}{c}\text { Year } \\
\text { left } \\
\text { industry }\end{array}$ & $\begin{array}{c}\text { District where } \\
\text { employed }\end{array}$ & $\begin{array}{c}\text { Year of } \\
\text { diagnosis }\end{array}$ & Histology & $\begin{array}{l}\text { Principal types } \\
\text { of dust to } \\
\text { which exposed }\end{array}$ & $\begin{array}{l}\text { Site of } \\
\text { tumour }\end{array}$ & Other work \\
\hline 439 & $\mathbf{F}$ & 1912 & 1927 & $\begin{array}{l}\text { Cotton } \\
\text { factory }\end{array}$ & $\begin{array}{l}\text { Winder and } \\
\text { spinner }\end{array}$ & 1962 & Manchester & 1961 & Adeno & Cotton & Unknown & \\
\hline 480 & $\mathbf{F}$ & 1895 & 1909 & $\begin{array}{l}\text { Cotton } \\
\text { factory }\end{array}$ & $\begin{array}{l}\text { Card room } \\
\text { assistant cotton } \\
\text { reeler }\end{array}$ & 1947 & Manchester & 1963 & Adeno & Cotton & Ethmoid & \\
\hline 452 & $\mathbf{F}$ & 1888 & 1903 & Cotton mill & Weaver & 1948 & Manchester & 1963 & Adeno & Cotton & $\begin{array}{l}\text { Nasal } \\
\text { cavity }\end{array}$ & \\
\hline 497 & $\mathbf{F}$ & 1894 & 1907 & Cotton mill & Hank winder & 1930 & Manchester & 1965 & Adeno & Cotton & Nasal & \\
\hline 482 & $\mathbf{F}$ & 1921 & 1935 & Unknown & $\begin{array}{l}\text { Making men's } \\
\text { braces }\end{array}$ & 1939 & Manchester & 1966 & Adeno & Cotton & Antrum & Clerk \\
\hline 446 & $\mathbf{F}$ & 1910 & 1942 & $\begin{array}{l}\text { Worsted } \\
\text { spinners }\end{array}$ & $\begin{array}{l}\text { Milling } \\
\text { machinist (also } \\
\text { Hoffmann } \\
\text { presser) }\end{array}$ & 1943 & Leeds & 1964 & Adeno & $\begin{array}{l}\text { Wool (cloth } \\
\text { dust) }\end{array}$ & Ethmoid & $\begin{array}{l}\text { Hoffman press } \\
1928-42\end{array}$ \\
\hline 445 & $\mathbf{F}$ & 1905 & (1919) & Millinery & Milliner & $\begin{array}{c}1925 \\
1945-64\end{array}$ & London & 1967 & Adeno & $\begin{array}{l}\text { Fur, felt, } \\
\text { straw }\end{array}$ & Ethmoid & \\
\hline 476 & $\mathbf{F}$ & 1898 & $\underset{\text { known }}{\text { Un- }}$ & Unknown & Dressmaker & $\begin{array}{c}\text { Un- } \\
\text { known }\end{array}$ & London & 1963 & Adeno & $\begin{array}{l}\text { Cotton and } \\
\text { other material }\end{array}$ & $\begin{array}{l}\text { Nasal } \\
\text { cavity }\end{array}$ & Shopkeeper ${ }^{1}$ \\
\hline 458 & $\mathbf{M}$ & 1886 & 1900 & $\begin{array}{l}\text { Cotton } \\
\text { fabric } \\
\text { industry }\end{array}$ & $\begin{array}{l}\text { Office boy to } \\
\text { company } \\
\text { chairman }\end{array}$ & $\begin{array}{c}1965 \\
\text { (Died) }\end{array}$ & Manchester & 1962 & Adeno & Cotton & $\begin{array}{l}\text { Nasal } \\
\text { cavity }\end{array}$ & 1 \\
\hline 432 & $\mathbf{M}$ & 1911 & $\begin{array}{c}\text { Un- } \\
\text { known }\end{array}$ & $\begin{array}{l}\text { Carpet } \\
\text { manufact. }\end{array}$ & Carpet weaver & 1967 & Birmingh am & 1967 & Adeno & Wool & Ethmoid & \\
\hline 528 & $\mathbf{M}$ & 1898 & 1920 & $\begin{array}{l}\text { Bleach } \\
\text { works }\end{array}$ & Linen finisher & 1956 & Birmingham & 1962 & Adeno & Linen & Antrum & Cleaner \\
\hline 518 & $\mathbf{M}$ & 1893 & 1933 & $\begin{array}{l}\text { Sewing } \\
\text { firm }\end{array}$ & $\begin{array}{l}\text { Machine } \\
\text { assistant }\end{array}$ & 1938 & Manchester & 1964 & Adeno & Cotton & Antrum & Garage prop.' \\
\hline 521 & $\mathbf{F}$ & 1910 & 1904 & Cotton mill & Sorter, carder & 1964 & Manchester & 1964 & Adeno & Cotton & Unknown & \\
\hline 526 & $\mathbf{F}$ & 1903 & 1932 & $\begin{array}{l}\text { Worsted } \\
\text { spinner }\end{array}$ & $\begin{array}{l}\text { Winder, reeler, } \\
\text { warper }\end{array}$ & 1965 & Leeds & 1966 & Squamous & Wool & Antrum & \\
\hline 525 & $\mathbf{F}$ & 1897 & (1910) & $\begin{array}{l}\text { Textile } \\
\text { factory }\end{array}$ & Weaver & $\underset{\text { known }}{\text { Un- }}$ & Warwick & 1966 & Squamous & Cotton & Antrum & $\begin{array}{l}\text { Laundry } \\
\text { worker }\end{array}$ \\
\hline 523 & $\mathbf{F}$ & 1900 & 1914 & $\begin{array}{l}\text { Woollen } \\
\text { mill }\end{array}$ & Weaver & 1926 & Manchester & 1966 & $\begin{array}{l}\text { Mela- } \\
\text { noma }\end{array}$ & Wool & Unknown & \\
\hline 520 & $\mathbf{M}$ & 1921 & 1937 & Cotton mill & $\begin{array}{l}\text { Packer- } \\
\text { winding room; } \\
\text { mule spinner }\end{array}$ & 1954 & Manchester & 1964 & $\begin{array}{l}\text { Histology } \\
\text { uncertain; } \\
\text { not adeno }\end{array}$ & Cotton & Unknown & \\
\hline 522 & $\mathbf{M}$ & 1913 & 1927 & Cotton mill & $\begin{array}{l}\text { Lad in packing } \\
\text { room }\end{array}$ & 1929 & Manchester & 1966 & Histology & Cotton & Unknown & $\begin{array}{l}\text { Window } \\
\text { cleaner }^{1}\end{array}$ \\
\hline 519 & $\mathbf{M}$ & 1888 & 1902 & Cotton mill & Cot packer & 1921 & Manchester & 1963 & $\begin{array}{l}\text { Mela- } \\
\text { noma }\end{array}$ & Cotton & Unknown & \\
\hline 524 & $\mathbf{M}$ & 1903 & 1915 & Cotton mill & Spinner & 1932 & Manchester & 1966 & $\begin{array}{l}\text { Mela- } \\
\text { noma }\end{array}$ & Cotton & Unknown & $\begin{array}{l}\text { Plater-de } \\
\text { Havilland }\end{array}$ \\
\hline
\end{tabular}

Male not listed as textile worker in Table 4.

other than adenocarcinoma in furniture workers will come as no surprise to pathologists. A reappraisal of the published material from the original survey from Oxford shows that four nasal tumours other than adenocarcinomas ( 2 transitional cell, 1 squamous, and 1 anaplastic) had arisen in Buckinghamshire furniture workers up to the end of 1967, two in males and two in females. It is extremely difficult to calculate a realistic 'expected' figure. Using generous assumptions, namely that the average annual risk of nasal cancer in the general population of both sexes is 10 per million and that the population of furniture workers at risk was $5,000,0.5$ cases would be expected over a decade. Of the 18 cases reported in Belgian woodworkers, two were squamous tumours and one was an undifferentiated tumour (Debois, 1969). One of the 17 woodworkers reported by Gignoux and Bernard (1969) as suffering from nasal cancer had a reticulum-cell sarcoma.

There is also evidence in this paper that certain woodworkers outside the furniture industry may be at risk in respect of nasal cancer. Indeed, in view of the overlap which exists between the type of work carried out by carpenters and joiners, and cabinet makers and machinists, it would be surprising if this were not so. Table 5 b lists eight patients in whom there is sufficient occupational data to be virtually certain that they never worked in the furniture industry. In Table 5c the nature of the industry in which the six men worked is uncertain. There is a suggestion in the material that the relative frequency of nasal tumours other than adenocarcinomas in 
woodworkers outside the furniture industry is higher than in woodworkers within the furniture industry. Thus, in Table 5a, 4 of 29 furniture workers had miscellaneous nasal tumours other than adenocarcinoma, as compared with 5 of 14 in workers whose relationship with the furniture industry was non-existent or uncertain (Tables $5 \mathrm{~b}$ and c) $\left(\chi^{2}=1 \cdot 6, \mathrm{n}=1, \mathrm{P}<0 \cdot 10\right)$. Both these points require to be re-examined in a larger survey before a definite conclusion can be reached.

Acheson and his colleagues (1970a) have published evidence showing an increased incidence of nasal adenocarcinoma and of other nasal tumours in workers in the Northamptonshire boot and shoe industry. The risk is virtually limited to the small number of workers in the industry-principally men - who have been exposed to dusty work in the preparation and finishing departments (Acheson et al., 1970b). A risk in boot and shoe repairers was also suggested. In the national survey reported here, substantially more leather workers with adenocarcinoma were ascertained than would be expected if the risk of the tumour were similar in all occupational groups (Table 4). Four patients with squamous tumours who had been leather workers were also found but only one of these qualified for inclusion in this category in Table 4, as they had left the industry after working in it for a relatively short period. The evidence is thus in harmony with that obtained from the Northamptonshire industry, in which three further cases of squamous carcinoma of the nasal cavity have occurred since the publication of the paper referred to above.

One of the most interesting and unexpected findings of this survey has been the group of tumours in persons who have been exposed to the dust of various textiles. Of the 20 patients listed in Table 6, 14 had been exposed to cotton, four to wool, one to linen, and one to fur, felt, and straw. As might be expected, many of these patients are women who worked in the industry for a relatively short period many years before the tumour developed. This adds greatly to the problem of determining the appropriate population at risk and of calculating the number of cases which would be expected if the risk of nasal cancer were not increased. More work is therefore needed before any firm conclusions may be drawn from this material.

No additional evidence has been found in this survey in support of the tentative suggestion in the Northamptonshire study of a possible relationship between nasal adenocarcinoma and the inhalation of flour dust.

This survey was planned at a point in the progress of the studies of nasal cancer in the Buckinghamshire furniture industry when it seemed likely that there might be specific relationships between the histological type of the tumour and the external environmental cause. It was for this reason that complete ascertainment was attempted only for adenocarcinomas, study of the other histological types of nasal cancer being limited to a sample of matched controls. It is now clear that the relationship between histological type of tumour and cause are complex and that a survey of all patients with nasal cancer over a number of years should be the next step. This is being undertaken.

\section{References}

Acheson, E. D., Cowdell, R. H., Hadfield, E., and Macbeth, R. G. (1968). Nasal cancer in woodworkers in the furniture industry. Brit. med. J., 2, 587-597.

Northamptonshire boot and shoe industry. Brit. med.J., 1, 385-393.

1, , and - (1970b). Nasal cancer in the shoe industry. Brit. med. J., 2, 791. (Letter)

Debois, J. M. (1969). Tumoren van de neusholte bij houtbewerkers. Tijdschr. v. Geneeskunde, 2, 92.

Gignoux, M., and Bernard, P. (1969). Tumeurs malignes de l'ethmoïde chez les travailleurs du bois. J. Med. Lyon, 50, 731-736.

Mosbech, J., and Acheson, E. D. (1971). Nasal cancer in furniture makers in Denmark. Dan. med. Bull., in press.

Received for publication March 27, 1971. 